\title{
The Factors Affecting Household Electricity Saving Behavior: A Study in Vietnam
}

\author{
Nguyen Ngoc Hien*, Pham Hoang Chi \\ Faculty of Business Administration, Industrial University of Ho Chi Minh City, Ho Chi Minh City 700000, Vietnam
}

Corresponding Author Email: nguyenngochien.qn@iuh.edu.vn

https://doi.org/10.18280/ijsdp.150810

Received: 11 September 2020

Accepted: 23 November 2020

\section{Keywords:}

planned behavior theory, perceived benefit, policy and social propaganda, intention of saving electricity, electricity saving behavior

\begin{abstract}
In the context of dramatically increase in electricity demand, Vietnam's potential for power supply remains limited. Research and promotion of electricity saving behavior of households become significant to reduce electricity consumption and protect ecological environment. This study incorporates elements of planned behavior theory (TPB) and norm activation model (NAM) as the basis for developing and extending key assumptions. In addition, expansion TPB is used to study influence factors affecting electricity saving behavior. Through a sample of 395 randomly selected residents in Tay Ninh Province and Ho Chi Minh city in Vietnam, the proposals were checked using a structural equation model (SEM). The results showed that the factors in TPB and NAM (such as perceived behavioral control, subjective norm, attitude, personal moral norm) and additional factor (perceived benefit) are the important factors that influence resident's intention of saving electricity. Moreover, electricity saving behavior is strongly influenced by the intention of saving electricity, perceived benefit, policy and social propaganda. Based on these results, some inferences are drawn, and recommendations are made for policy makers and further research proposals are discussed.
\end{abstract}

\section{INTRODUCTION}

With the rapid development of the economy, along with the process of industrialization, modernization and population growth, the demand for electricity use in Vietnam is rocketing. Whereas, in recent years, that demand has increased by $12 \%$ to $16 \%$ per year $[1,2]$. The intensity of energy consumption in Vietnam is among the highest in the region and around the world. According to decision No. 428/QD-TTg dated March 18,2016 , approving the adjustment of the national electricity development plan for the period between 2011 and 2020 with a vision to 2030, the demand for electricity in Vietnam will continue to grow at the rate of $7.4 \%$ to $8.4 \%$ per annum from 2021 to 2030 [3]. Since 2015, Vietnam has become an energy importer even though the country had been an exporter [2]. Consequently, ensuring energy supply has become an essential issue for the economy. At present in Vietnam, large hydroelectric resources have been fully exploited; Nuclear power projects have been halted; and renewable energy, although potentially still accounting for only a small percentage of total generation capacity [2]. Demand for electricity continues to increase, but Vietnam's potential to develop electricity supply faces many limitations such as environmental problems, out of resources, sustainable development, etc. As a result, saving energy becomes a priority in all sectors of the economy, including residential areas. Reasonable and economical use of electricity contributes to the power industry, environmental protection and energy security of the country. Moreover, it is also the least expensive way to avoid raising in power generation capacity but still meet the increasing demand for electricity.

Theoretically, research on household's electricity saving behavior can be divided into 3 different perspectives including the perspective of studying the influence of economic factors, the perspective of technology orientation and psychological behavior oriented perspective [4]. (1) The view of economic orientation is based on price policies and financial incentives [5]. However, in the context of increasing household incomes, people are less sensitive to the changes of electricity price, which is compatibly low. Thus, they are not willing to sacrifice comfortably daily lifestyle for saving energy [6]. Therefore, it is not effective to focus only on economic factors to save electricity [7]. (2) The technology-oriented view focuses on approaches promoting the use of energy-efficient technologies and devices to save and reduce power consumption [5]. However, according to Nilsson et al. [8] energy saving technology has improved a lot and the device's energy efficiency has developed significantly over the past decades, but the consumption of household electricity consumption is still increasing. As such, relying on technology is not enough to reduce the electricity consumption and (3) A number of scholars have emphasized the importance of psychological factors in achieving power-saving goals [4, 9]. Opinions orient psychological behavior by emphasizing a number of psychological factors such as attitudes, environmental awareness and social norms to promoting electricity saving behavior [10]. Many studies have emphasized the importance of economic and psychological factors to encourage energysaving behavior in families [11-13].

Shortly, there are many different views on electricity saving behavior, but the majority of researches have been conducted in developed countries while a very few studies have been carried out in developing countries with a context similar to Vietnam. Moreover, in addition to the factors that have been considered in previous studies such as attitudes, subjective norm, perceived behavioral control and personal moral norm, 
this study examines the role of perceived benefit, policy and social propaganda in encouraging electricity saving intentions and behaviors.

This research presents certain theoretical and practical contributions. Theoretically, the study expanded the theory of planned behavior (TPB) to examine the factors affecting electricity saving behavior in the context of Vietnam. Moreover, the factors of perceived benefits, policies and social propaganda were added to the model to further assess the impact of these two factors on the intention and behavior of electricity consumers. In practice, the research contributes empirical evidence to help policy managers and Vietnam electricity in improving electricity saving behavior of the people, and contributes to the success of the national program on using energy economically and efficiently in the period from 2019 to 2030 .

\section{LITERATURE REVIEW}

\subsection{Intention and electricity saving behavior}

According to Ajzen [14], behavioral intent is considered as a combination of motivational factors that influence the behavior of each individual, which shows the willingness or effort that each individual will spend to perform the behavior. Most human behaviors are predictable based on intentions because behaviors are obeyed to the will and under the control of intention. intention of behavior to be seen as an intermediate premise of behavior.

Energy in general or electricity in particular is a specific product needed for everyday life. Whether you like it or not, every family must buy and use. Electricity saving behavior is the act of shutting down when not needed, using highefficiency electricity, investing in energy-saving devices to reduce electricity consumption. Effective use is to use the least amount of energy and still satisfy the demand. The intention of saving electricity is an important and positive predictor of household energy saving behavior [4]. It is implied that in most studies about consumer behavior, intention and behavior are considered as one factor or if there are differences, the relationship between them is also very close. In fact, summarizing the empirical results and the rational action theory of Ajzen and Fishbein [15], the inconsistency between intent and behavior in different consumption sectors was also mentioned.

In the field of electricity consumption, electricity saving behavior is not only affected by psychological factors, but also by external factors. Whereas, external factors not only directly affect energy saving behaviors, but also indirectly through subjective norms of individual. Thus, external factors are more effective for electricity saving behavior [13]. Previous studies have shown that perceived benefits such as economic benefits, environmental benefits, and organizational benefits have a positive impact on the electricity saving intention $[5,16,17]$. In addition, energy saving behavior is closely related to government laws and regulations. The government can develop policies and regulations to encourage energy saving behaviors. Energy policymakers can influence campaigndriven electricity saving behavior through the media, government, schools and other disciplines [18-20].

\subsection{Theoretical background}

According to Abrahanse and Steg [11], the norm activation model [21] considered environmental support as a form of altruism, when individuals must abandon their personal interests for the benefit of the collective (i.e., environment). Altruistic behavior is determined by individual ethical standards, in which moral experience and obligations are the two basic elements. One conducts an action according to one's personal moral norms can lead to a sense of pride, and vice versa, which can bring a sense of guilt. The norm activation model (NAM) has been used for a variety of proenvironmental behaviors such as energy conservation [22].

Moreover, this study also relies on TBP (Theory of Planned Behavior) to develop research hypotheses. According to Ajzen [23], TPB was the development and improvement of TRA (Theory of Reasoned Action). In addition to the concepts of attitude and subjective norm, the third concept, that Ajzen deemed influences on human intent, was perceived behavior control. Whereas, Perceived behavior control reflects how easy or difficult it is to perform a behavior and whether its behavior is controlled or limited [14]. The more resources and opportunities, they think, the less barriers there will be and the greater the awareness control for behavior. In this study, we combine the theory of TPB and NAM as a basis for developing and extending the main hypotheses.

\section{RESEARCH FRAMEWORK AND HYPOTHESIS DEVELOPMENT}

\subsection{Basic variables in TPB and NAM}

According to TBP [14], the factor that drives actual behavior is the intention to perform that behavior. Intention is determined by three factors: attitude, subjective norm and perceived behavior control. Firstly, attitude is the most important variable that affects an individual's intention to behave. Attitude reflects an individual's positive or negative assessment of a given behavior [24], measured by the belief that it is helpful to perform the behavior. Some studies, such as Webb et al. [25] and Yadav and Pathak [26], noted the importance of attitude in predicting environmentally friendly behavior in different contexts like household energy-saving behavior, green product purchasing behavior and using green vehicles for transportation. Similarly, in the context of energysaving behavior, one can speculate that if an individual considers energy-saving behavior to be very important, valuable and beneficial for reducing carbon emissions, they will maintain a positive attitude and may form the intention of saving electricity. Secondly, subjective norms are the community factors that pressure from people around them or community pressure is able to affect people intending to perform a behavior. If people, who are important to individuals, expect them to perform a specific action to save energy, such as turning on lights only in their living areas, turning off lights when not in use, etc., they are more likely to engage in energysaving behaviors. Thirdly, perceived behavior control is the awareness of the available resources and the ability to seize opportunities when committing a specific behavior. When individuals believe that they have a lot of resources, their perceived behavior control will increase. For example, a person may not be willing to reduce energy use because they find it difficult to do so.

Applying the TBP in the context of efficient electricity use, it can be deduced that, (1) when people have a positive attitude towards saving electricity, (2) they think that those around 
them want if they save electricity and (3) they can afford the resources and opportunities to perform the behavior, the leader's energy saving intentions will increase. Therefore, it is assumed that:

H1: Attitude is positively related to the household's intention of saving electricity.

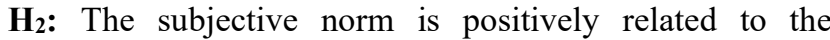
household's intention of saving electricity.

$\mathbf{H}_{3}$ : Perceived behavior control is positively related to the household's intention of saving electricity.

Bertoldo and Castro [27] confirm that Personal moral norm is an individual to take action based on their moral responsibility. In the NAM model, personal moral norm is considered core elements [24]. The individual's environmental behavior is determined by his personal ethical standards and social ethical standards [28]. The more personal ethical standards will motivate the individual to engage in environmental behavior and vice versa, when an individual has a low personal moral standard, it will hinder environmental behavior [29]. In this study, it is reasonable to predict that residents with high personal moral norm will feel more responsible for saving electricity compared to others. They consider that saving electricity is an obligation, which every citizen must contribute to national energy security and protect the ecological environment. Waste of electricity or not saving electricity are the action that do not follow their ethical standards and obligations leading them to be uncomfortable. Therefore, we can speculate that the greater the morality of a person with a higher personal moral norm, the greater the likelihood of saving energy. Thus, we suppose that:

H4: Personal moral norm has a positive effect on the household's intention of saving electricity.

Based on the same logic, consistent with TBP [14], we also predict that people's intention of saving electricity is an important and positive predictor of household's saving behavior. The greater the intention of saving electricity, the higher the act of saving electricity. Therefore, I hypothesize that:

H5: Intention of saving electricity has a positive effect on household electricity saving behavior.

\subsection{Perceived benefit}

According to Orbell et al. [30] perceived benefit refers to the ability to perceive that a proposed action will lead to a positive outcome. Perceived benefit is a type of cognitive emotion, which positively affects an individual's behavior [31]. It is defined as the degree to which an individual believes that he or the whole society will gain benefit from doing an act [32]. Research results of Banfi et al. [33] showed that the benefits of energy saving were highly valued by consumers. These benefits included both personal energy savings and environmental benefits. Research by Wang et al. [16] presented that economic benefits (reduction in spending due to electricity savings) had a positive effect on residents' electricity saving behavior. Zhang et al. [17] pointed out that environmental benefits and organizational benefits positively influenced employees' attitudes towards energy savings. Thus, saving electricity leads to costs reduction. It also helps to save natural resources and protect the environment. If the household is aware of these benefits, they are likely to appreciate energy savings, thus developing a positive attitude towards saving energy. So, suppose that:

H6a $_{\text {: }}$ Perceived benefits have a positive effect on a household's intention of saving electricity.

Hob: Perceived benefits have a positive effect on household electricity saving behavior.

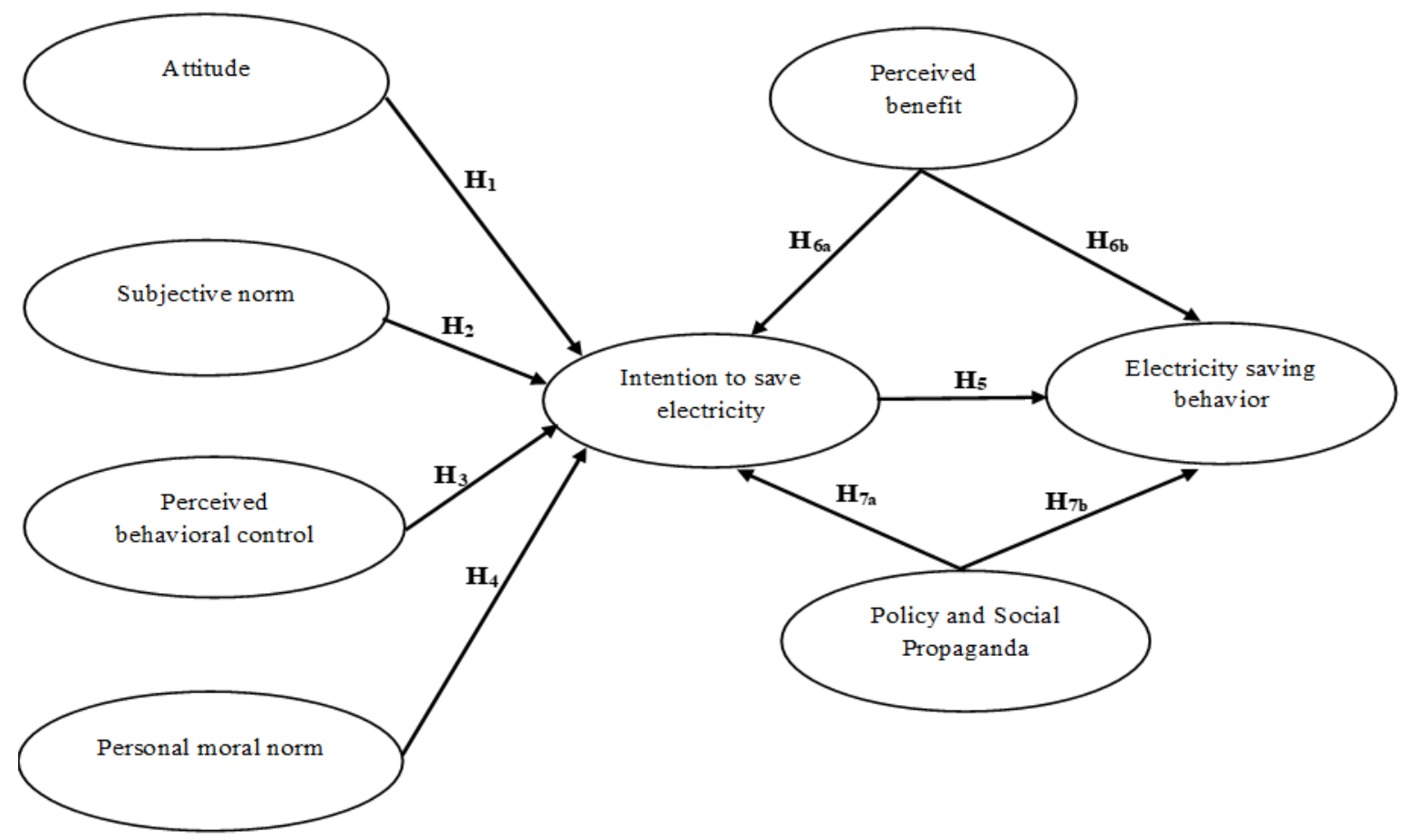

Figure 1. Research model of household electricity saving behavior (Source: Author synthesized from research hypothesis) 


\subsection{Policy and social propaganda}

Policy is an action of state using the power and resources to promote a priority value [34]. The energy saving policy is basically a type of regulatory policy [18]. Energy policies are effective in reducing energy intensity [35]. According to Wang et al. [16], social policies and regulations have a significant impact on shaping and changing energy-saving behaviors of residents. The choice of performing energy-saving behaviors is closely related to government laws and regulations. In other words, the government can develop energy conservation policies and regulations to encourage household energysaving behaviors [19]. Relating to Nelson [36], propaganda is a form of persuasion to influence the emotions, attitudes, opinions and actions of the target audience through the transmission of controlled one-way messages by means of communication informed. For motivating energy-saving action, households must be aware of energy-saving solutions [37]. There are many different approaches to disseminate the information, such as leaflets, advertising campaigns, and device energy labeling [38]. According to Wang et al. [16], people, who hold more information and have a better understanding of electricity-related policies, are more willing to participate in saving electricity than others. Fully disseminating information is often the result of regular propaganda of energy saving and environmental protection via the media. By using the media, government, schools and related industries can able to change personal attitudes and then instruct households to increasingly engage in energysaving behaviors such as using daily public transport or walking instead of using a private car [19]. To study the effect of policy and propaganda on household electricity saving behavior, the following hypotheses were developed:

$\mathbf{H}_{7 a}$ : Policy and social propaganda have a positive influence on households' intention of saving electricity.

H$_{7 \mathrm{~b}}$ : Policy and social propaganda have a positive influence on household's electricity saving behavior.

\subsection{Research model}

Based on TBP, NAM and previous studies. The proposed research model consists of 9 hypotheses (Figure 1).

\section{METHODOLOGY}

\subsection{Survey instrument}

The scale of concepts in this study is based on previous scales and made some adjustments to fit this research context. The intention of saving electricity scale is updated from the Wang et al. [4] scale with 4 variables. The electricity saving behavior scale is also updated from the Wang et al. [4] scale including 4 variables. For the concept of attitude and perceived behavior control, the variables in the study of Wang et al. [4], Abrahamse and Steg [11] are inherited. There are five variables of the concept of attitude and 5 variables of cognitive behavioral control consistent within the context of this study. The subjective norms scale consists of 4 variables adjusted from Wang et al. [4]; Tan, Ooi and Goh [39]. The personal moral norm scale of Zhang et al. [19] with 7 variables are also implemented. The perceived benefit scale consists of 5 variables taken from Zhang et al. [17]. And finally, the four observed variables of the policy and social propaganda scale are adapted from Zhang et al. [19]. All structural scales in the research model are measured by 5-point Likert scale from Strongly Disagree (1) to Strongly Agree (5).

A questionnaire is constructed as follows: First, a brief introduction about the survey. Next, a clarifying question to focus on customers, who possess a home. Finally, the questionnaire consists of 2 main parts. Part one includes demographic questions (Table 1) and part two includes questions about concepts in the research model.

The pilot survey was conducted in April 2020 to check the structure and content of the questionnaire. People living and using electricity in Ho Chi Minh city were selected to conduct data collection because Ho Chi Minh city is the largest and most developed city in Vietnam. Respondents were asked to answer all questions as instructed, then provided comments on the overall structure, as well as the clarity of the questions. Survey of 25 electricity users showed that most of the questions were agreed by participants. However, the content of some questions is still unclear. Questions measuring attitudes, personal norms, and perceived behavioral control have been adapted to suit local people (Adjusted results in Table 2). Data for pilot studies are not included in the main study.

Table 1. Structure of research sample $(n=395)$

\begin{tabular}{cccccc}
\hline Sex & Frequency & $\mathbf{\%}$ & Job & Frequency & $\%$ \\
\hline Male & 200 & 50.6 & Farmer & 51 & 12.9 \\
Female & 195 & 49.4 & Worker & 108 & 27.3 \\
Age & & & Small business & 33 & 8.4 \\
From 18-30 years old & 124 & 31.4 & State officials & 47 & 11.9 \\
From 31-40 years old & 195 & 49.4 & Teacher & 50 & 12.7 \\
From 50 years old and up & 76 & 19.2 & Engineer & 8 & 2.0 \\
Education & Frequency & $\mathbf{\%}$ & Medicine-Doctor & 6 & 1.5 \\
High school and below & 101 & 25.6 & Manage & 14 & 3.5 \\
Intermediate & 98 & 24.8 & Student & 18 & 4.6 \\
College & 178 & 45.1 & Unskilled labor & 15 & 3.8 \\
Postgraduate & 18 & 4.6 & Retirement & 20 & 5.1 \\
Family style & Frequency & $\mathbf{\%}$ & Other career & 25 & 6.3 \\
Alone & 111 & 28.1 & Income (VND) & Frequency & $\mathbf{\%}$ \\
1 generation family & 109 & 27.6 & Less than 5 million & 107 & 27.1 \\
2 generations family & 107 & 27.1 & From 5 to 10 million & 190 & 48.1 \\
Family with 3 generations or & 68 & 17.2 & From 10 to 15 million & 64 & 16.2 \\
more & & Over 15 million & 34 & 8.6 \\
\hline
\end{tabular}

Source: Author compiled from surveyed data 
Table 2. Confirmatory factor analysis for measurement items

\begin{tabular}{|c|c|}
\hline Factors/Items & Factor loading \\
\hline $\begin{array}{l}\text { Attitude (AT) }(\boldsymbol{\alpha}=\mathbf{0 . 9 3 7}, \mathbf{C R}=\mathbf{0 . 9 3 9}, \mathbf{A V E}=\mathbf{0 . 7 5 5}) \\
\text { AT1. Saving electricity in my home is important to reduce CO2 emissions } \\
\text { AT2. Saving electricity in my home is contributing to improve the air environment } \\
\text { AT3. Saving electricity at home is necessary } \\
\text { AT4. Quality of home life is still comfortable when saving electricity } \\
\text { AT5. The quality of home life is still guaranteed when saving electricity } \\
\text { Source: Adapted from Wang, Lin and Li [4], Abrahamse and Steg [11] }\end{array}$ & $\begin{array}{l}0.761 \\
0.848 \\
0.826 \\
0.945 \\
0.944\end{array}$ \\
\hline $\begin{array}{l}\text { Perceived behavioral control }(\mathrm{PBC})(\boldsymbol{\alpha}=\mathbf{0 . 9 1 0}, \mathbf{C R}=\mathbf{0 . 9 1 4}, \mathbf{A V E}=\mathbf{0 . 7 2 6}) \\
\text { PBC1. I understand what to do to save electricity } \\
\text { PBC2. I think it's not too difficult to reduce electricity use } \\
\text { PBC3. I know how to use electricity efficiently } \\
\text { PBC4. I can save electricity easily } \\
\text { Source: } \text { Adapted from Wang, Lin and Li [4], Abrahamse and Steg [11] }\end{array}$ & $\begin{array}{l}0.701 \\
0.915 \\
0.884 \\
0.886\end{array}$ \\
\hline $\begin{array}{l}\text { Subjective norm (SN) }(\boldsymbol{\alpha}=\mathbf{0 . 9 3 9}, \mathbf{C R}=\mathbf{0 . 9 3 9}, \mathbf{A V E}=\mathbf{0 . 7 9 5}) \\
\text { SN1. I save electricity because my neighbors do the same } \\
\text { SN2. Family members want me to use electricity economically } \\
\text { SN3. My friends want me to use electricity economically } \\
\text { SN4. Family members want me to buy products with energy-saving functions when I want to shop } \\
\text { Source: Adapted from Tan, Ooi and Goh [39] }\end{array}$ & $\begin{array}{l}0.847 \\
0.884 \\
0.829 \\
0.957\end{array}$ \\
\hline $\begin{array}{l}\text { Personal moral norm }(\mathbf{P M N})(\boldsymbol{\alpha}=\mathbf{0 . 8 5 0}, \mathbf{C R}=\mathbf{0 . 8 5 1}, \mathbf{A V E}=\mathbf{0 . 5 8 8}) \\
\text { PMN1. I have an energy-saving lifestyle to protect the environment } \\
\text { PMN2. Saving electricity is the duty of every citizen } \\
\text { PMN3. Do not save electricity when using is wasteful } \\
\text { PMN4. I still use electricity sparingly even though people around me do not } \\
\text { Source: } \text { Zhang et al. [13] }\end{array}$ & $\begin{array}{l}0.691 \\
0.704 \\
0.775 \\
0.879\end{array}$ \\
\hline $\begin{array}{l}\text { Perceived benefit }(\mathbf{P B})(\boldsymbol{\alpha}=\mathbf{0 . 8 3 0}, \mathbf{C R}=\mathbf{0 . 8 3 2}, \mathbf{A V E}=\mathbf{0 . 5 5 3}) \\
\text { PB1 Saving electricity contributes to protect the ecological environment } \\
\text { PB2. Saving electricity reduces family costs } \\
\text { PB3. Saving electricity is beneficial for the family } \\
\text { PB4. My family will benefit when I save electricity } \\
\text { Source: Adapted from Zhang, Wang and Zhou [17] }\end{array}$ & $\begin{array}{l}0.672 \\
0.820 \\
0.736 \\
0.736\end{array}$ \\
\hline $\begin{array}{l}\text { Policy and Social Propaganda (PSP) }(\alpha=0.945, C R=0.946, A V E=0.814) \\
\text { PSP1. I save electricity because of relevant policies and regulations } \\
\text { PSP2. Policies and regulations play an important role in promoting and encouraging me to save electricity } \\
\text { PSP3. I save electricity because I am influenced by the information received from newspapers, television and the media } \\
\text { PSP4. I save electricity because I am instructed on how to use electricity efficiently and regularly } \\
\text { Source: Adapted from Zhang et al. [19] }\end{array}$ & $\begin{array}{l}0.903 \\
0.830 \\
0.843 \\
0.987\end{array}$ \\
\hline $\begin{array}{l}\text { intention of saving electricity (INT) }(\boldsymbol{\alpha}=\mathbf{0 . 9 0 4}, \mathbf{C R}=\mathbf{0 . 9 0 7}, \mathbf{A V E}=\mathbf{0 . 7 0 9}) \\
\text { INT1. I plan to save electricity in my home } \\
\text { INT2. I will plan to save electricity in my house } \\
\text { INT3. I will endeavor to save electricity in my home } \\
\text { INT4. I will use the device appropriately to save electricity } \\
\text { Source: } \text { Adapted from Wang, Lin and Li [4] }\end{array}$ & $\begin{array}{l}0.770 \\
0.855 \\
0.791 \\
0.936\end{array}$ \\
\hline $\begin{array}{l}\text { Electricity saving behavior }(\mathbf{B E H})(\boldsymbol{\alpha}=\mathbf{0 . 8 9 3}, \mathbf{C R}=\mathbf{0 . 8 9 5}, \mathbf{A V E}=\mathbf{0 . 6 8 2}) \\
\text { BEH1. I always turn off electrical appliances when there's nobody in the room } \\
\text { BEH2. I always turn off electrical appliances completely instead of in standby } \\
\text { BEH3. I have recently purchased devices with power saving functions } \\
\text { BEH4. I have replaced old devices with energy-saving devices recently } \\
\text { Source: Adapted from Wang, Lin and Li [4] }\end{array}$ & $\begin{array}{l}0.758 \\
0.862 \\
0.782 \\
0.892\end{array}$ \\
\hline
\end{tabular}

\subsection{Sample and data collection}

An official survey was conducted after adjusting the questionnaire according to customers' opinions in the pilot survey. Direct surveys were conducted at households using electricity. To increase enthusiasm, participants, who are notified after completing the questionnaire, will receive a gift. This study was conducted in Ho Chi Minh City and Tay Ninh Province based on convenient sampling techniques. Ho Chi Minh City is one of the largest cities in Vietnam with a population of over 10 million people, where the annual electricity consumption increases by over $10 \%$. Therefore, saving electricity is an urgent goal of this city. In addition, the study also sampled in Tay Ninh province representing the average development provinces in Vietnam. Respondents were initially asked to answer questions related to demographics (gender, age, education, occupation, family type, income), followed by answering questions related to electricity consumption. The survey period was from May 10, 2019 to May 30, 2020. The number of questionnaires issued was 550, after eliminating inappropriate questionnaires (incomplete answers, having the same answers for all questions), a total of 395 valid questionnaires were analyzed to evaluate the reliability, validity and relevance of the hypotheses. 


\section{RESULTS}

\subsection{Demographics of respondents}

Demographic characteristics of the research sample were tested (Table 2). The proportion of men and women in the sample was nearly the same (50.6\% compared to $49.4 \%)$. The gender ratio of respondents is consistent with the demographic characteristics of Vietnam (General Statistics Office of Vietnam 2019). The surveyed ages ranged from 18 to over 50 years old, in which the ages from 31-50 were accounted for the highest proportion. In terms of education, most people had college - university degrees. Respondents in the age group from 18 to 40 years old are accounted for a proportion of $80.8 \%$. This is the main force in working age. They are working in many different professions, in which many fields require professional qualifications. Therefore, the high proportion of respondent graduated from college-university is required. Following was the family style with nearly equal distribution. In addition, the career distribution of the survey subjects was very diverse including many different occupations. Finally, income from 5 to 10 million VND made up the highest rate.

According to previous studies, demographic factors such as education level, household income and age, etc. do not have a clear influence on electricity saving behavior [40-42].

\subsection{Measurement model}

Measurement model was evaluated through confirmation factor analysis (CFA) by software amos 20.0. The model fit indices are listed as follows: the ration of Chisquare to degree of freedom $(\chi 2 / \mathrm{df})$ is $1,448<3$, Comparative fit index (CFI) is $0.979>0.9$, Tucker-Lewis index (TLI) is $0.976>0.9$, Goodness of fit index (GFI) is $0.907>0.9$, and Root mean square error of approximation (RMSEA) is $0.034<0.08$. This shows that the measurement model is consistent with the actual data [43]. As shown in Table 2, all Cronbach's alpha values are in the range from 0.83 to 0.945 , which is greater than the minimum threshold of 0.6 . The composite reliability value is greater than 0.6 . Thus, the scales are highly reliable [44]. To evaluate the convergent validity of the constructs, individual item loading and average variance extracted (AVE) are used [45]. The CFA results indicate that, the loadings are significant at $p<0.001$ and greater than the threshold value of 0.50 . So, all items are significantly loaded on the constructs [46].

To test the value of distinguishing between structures, the method of comparison between AVE and the correlation coefficient is used. As shown in Table 3, the square root of the
AVE values is greater than all the correlations between the structures. Therefore, it can be concluded that the reliability and validity of the latent constructs are acceptable [46]. All structures satisfy that the square root of AVE value for each structure must be greater than 0.5 (square roots of AVE ranges from 0.744 to 0.902 in Table 3 ). In addition, the square roots of AVE give two structures larger than the correlation between inter-construct correlations, which suggests that the structures reach discriminatory values [45]. Table 3 presents the mean, standard deviations, correlation matrix and square roots of AVE in all structures included in the research model.

\subsection{Structural model}

To estimate the relationship in a research model, Structural Equation Modeling is used because it is a very useful statistical process in surveys using cross-sectional data. Structural Equation Modeling (SEM) incorporates many models regression and factor analysis to evaluate measurement scales and test research hypotheses [47]. The result of testing structural model (Figure 2) shows that the model has 471 degrees of freedom with $\mathrm{P}$-value $=0.00<0.05$. The indicators are consistent with real data (Chi-quare / $\mathrm{df}<3$; CFI, GFI, TLI $>$ 0.9 , RMSEA < 0.08)

The estimation results of regression coefficients in the model (Table 4) show that the relationships are statistically significant because of the $\mathrm{p}$-value $<0.05$. Intention of saving electricity is positively affected by Attitude $(\beta=0.144, \mathrm{p}<$ $0.01)$, Subjective norm $(\beta=0.165, p<0.01)$, Perceived behavioral control $(\beta=0.245, \mathrm{p}<0.01)$, Personal moral norm $(\beta=0.174, p<0.01)$, Perceived benefits $(\beta=0.191, \mathrm{p}<0.01)$ and Policy and social propaganda $(\beta=0.137, \mathrm{p}<0.05)$. In addition, electricity saving behavior is significantly influenced by the intention of saving electricity $(\beta=0.309, \mathrm{p}<0.01)$, Perceived benefit $(\beta=0.247, \mathrm{p}<0.01)$, and Policy and social propaganda $(\beta=0.135, \mathrm{p}<0.05)$.

\subsection{Discussion of the research results}

This study uses a comprehensive model, which incorporates not only traditional cognitive factors in the TBP theoretical model (attitude, subjective norm and perceived behavioral control) but also the non-factor awareness of personal moral norm, along with perceived benefit, policy and social propaganda. The aim is to clearly understand the factors affecting consumers' electricity saving behavior. The results of this research emphasize the importance of the benefits, policies and propaganda to the intention and behavior of saving electricity of residents.

Table 3. Mean, standard deviations, correlation matrix and square roots of AVE

\begin{tabular}{ccccccccccc}
\hline Constructs & Mean & SD & INT & AT & PSP & PB & SN & PBC & PMN & BEH \\
\hline INT & 2.78 & 0.77 & $\mathbf{0 . 8 4 2}^{\text {a }}$ & & & & & & & \\
AT & 2.73 & 0.82 & 0.333 & $\mathbf{0 . 8 5 0}$ & & & & & & \\
PSP & 3.70 & 0.84 & 0.469 & 0.257 & $\mathbf{0 . 9 0 2}$ & & & & & \\
SN & 3.74 & 0.76 & 0.500 & 0.227 & 0.568 & $\mathbf{0 . 8 9 2}$ & & & & \\
PBC & 3.54 & 0.81 & 0.493 & 0.231 & 0.365 & 0.435 & $\mathbf{0 . 8 5 2}$ & & & \\
PMN & 2.83 & 0.82 & 0.424 & 0.157 & 0.341 & 0.280 & 0.312 & $\mathbf{0 . 7 6 7}$ & & \\
PB & 2.94 & 0.54 & 0.412 & 0.170 & 0.271 & 0.356 & 0.203 & 0.299 & $\mathbf{0 . 7 4 4}$ & \\
BEH & 2.81 & 0.74 & 0.477 & 0.215 & 0.349 & 0.276 & 0.231 & 0.198 & 0.415 & $\mathbf{0 . 8 2 6}$ \\
\hline
\end{tabular}

${ }^{a}$ Numbers in bold represent the square roots of AVE

Source: Author compiled from surveyed data 


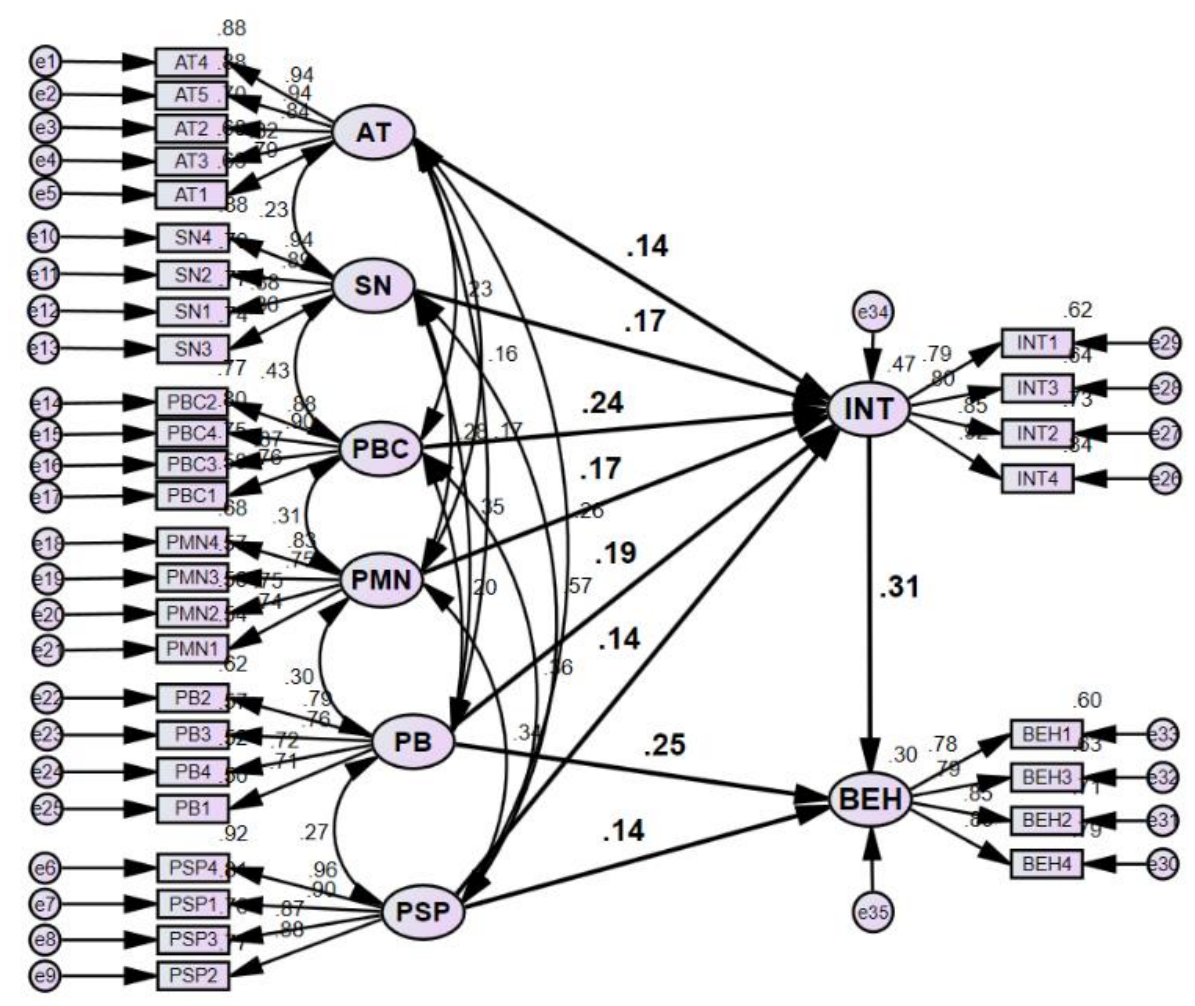

Chi-square $=681.814 ; \mathrm{df}=471 ; \mathrm{P}=0,000$

Chi-square $/ \mathrm{df}=1.448 ; \mathrm{GFI}=0.907 ; \mathrm{TLI}=0.976$ $\mathrm{CFI}=0.979 ; \mathrm{RMSEA}=0.034$

Figure 2. SEM analysis results of theoretical model (standardized) Source: The author uses Amos 20.0 software to analyze data

Table 4. Regression coefficients in the theoretical model

\begin{tabular}{|c|c|c|c|c|c|c|c|c|c|}
\hline \multirow{2}{*}{$\begin{array}{c}\text { Hypothesis } \\
\mathrm{H}_{1}\end{array}$} & \multicolumn{3}{|c|}{ Relationship } & \multirow{2}{*}{$\begin{array}{c}\begin{array}{c}\text { Regression } \\
\text { Weights }\end{array} \\
0.141\end{array}$} & \multirow{2}{*}{$\begin{array}{c}\begin{array}{c}\text { Standardized } \\
\text { Regression Weights }\end{array} \\
0.144\end{array}$} & \multirow{2}{*}{$\begin{array}{c}\text { SE } \\
.043\end{array}$} & \multirow{2}{*}{$\frac{\mathbf{C R}}{3.300}$} & \multirow{2}{*}{$\begin{array}{c}\begin{array}{c}\mathbf{p}- \\
\text { value }\end{array} \\
.000\end{array}$} & \multirow{2}{*}{$\begin{array}{l}\text { Result } \\
\text { Accept }\end{array}$} \\
\hline & Attitude & $\rightarrow$ & $\begin{array}{c}\text { intention of } \\
\text { saving electricity }\end{array}$ & & & & & & \\
\hline $\mathrm{H}_{2}$ & Subjective norm & $\rightarrow$ & $\begin{array}{c}\text { intention of } \\
\text { saving electricity }\end{array}$ & 0.175 & 0.165 & .059 & 2.943 & .003 & Accept \\
\hline $\mathrm{H}_{3}$ & $\begin{array}{c}\text { Perceived } \\
\text { behavioral } \\
\text { control }\end{array}$ & $\rightarrow$ & $\begin{array}{c}\text { intention of } \\
\text { saving electricity }\end{array}$ & 0.252 & 0.245 & .052 & 4.892 & .000 & Accep \\
\hline $\mathrm{H}_{4}$ & $\begin{array}{c}\text { Personal moral } \\
\text { norm }\end{array}$ & $\rightarrow$ & $\begin{array}{c}\text { Intention to save } \\
\text { electricity }\end{array}$ & 0.173 & 0.174 & .050 & 3.466 & .000 & Accept \\
\hline $\mathrm{H}_{5}$ & $\begin{array}{c}\text { intention of } \\
\text { saving electricity }\end{array}$ & $\rightarrow$ & $\begin{array}{c}\text { Electricity saving } \\
\text { behavior }\end{array}$ & 0.274 & 0.309 & .053 & 5.139 & .000 & Accep \\
\hline $\mathrm{H}_{6 \mathrm{a}}$ & Perceived benefit & $\rightarrow$ & $\begin{array}{c}\text { intention of } \\
\text { saving electricity }\end{array}$ & 0.317 & 0.191 & .084 & 3.789 & .000 & Accep \\
\hline $\mathrm{H}_{6 b}$ & Perceived benefit & $\rightarrow$ & $\begin{array}{c}\text { Electricity saving } \\
\text { behavior }\end{array}$ & 0.364 & 0.247 & .085 & 4.268 & .000 & Accep \\
\hline $\mathrm{H}_{7 \mathrm{a}}$ & $\begin{array}{l}\text { Policy and Social } \\
\text { Propaganda }\end{array}$ & $\rightarrow$ & $\begin{array}{c}\text { intention of } \\
\text { saving electricity }\end{array}$ & 0.134 & 0.137 & .052 & 2.562 & .010 & Accep \\
\hline $\mathrm{H}_{7 \mathrm{~b}}$ & $\begin{array}{c}\text { Policy and Social } \\
\text { Propaganda }\end{array}$ & $\rightarrow$ & $\begin{array}{c}\text { Electricity saving } \\
\text { behavior }\end{array}$ & 0.116 & 0.135 & .047 & 2.481 & .013 & Accept \\
\hline
\end{tabular}

Source: The author uses Amos 20.0 software to analyze data

The results show that the intention of saving electricity is positively affected by the factors including attitude, subjective norm, perceived behavioral control and personal moral norm. This result is consistent with previous studies such as Abrahamse and Steg [11]; Fornara et al. [48]; Shi, Fan and Zhao [9] and Cheung et al. [6]. Contrary to Wang et al. (2018)'s study [4] suggested that subjective norm had a negligible influence on residents' intention of saving electricity. This study confirms the importance of family members, neighbors, friends, etc. to the intention of saving electricity of residents. Due to the characteristics of Vietnamese culture, people respect community and family values very much. Therefore, if people think that those who are important to them want to save electricity, they will have a high possibility to do the same. In addition, perceived benefit, policy and social propaganda also influence the intention of saving electricity. There are many previous studies presented similar concept such as Wang et al. [16]; Zhang et al. [19]. Regarding the degree of impact of the factors, perceived behavioral control factor in TBP theory are the most powerful 
one, followed by perceived benefits, while the remaining factors have the weakest effects. This result shows that, for households using electricity, the factors like how easy to implement measures, how to save electricity and how to use electricity economically without affecting the family activities, have an important influence on their intention of saving electricity.

Consumers' electricity saving intention is also positively influenced by perceived benefits, policies and social propaganda. The obtained result agrees with many previous studies of Wang et al. [16]; Wang et al. [4]; Zhang et al. [17]; Zhang et al. [19]. This study also shows that in the area of electricity consumption, behavioral intent cannot be considered as a proxy of behavior [4]. It is worth noting that the factors such as perceived benefit, policy and propaganda also have a significant influence on consumers' electricity saving behavior. The results of this study show that for households, they basically understand how electricity savings benefit their own families and the community. In addition, the State's regulations, policies and propaganda on electricity saving and Vietnam electricity industry have a positive effect and contribution to change the behavior of economical use of electricity by households.

In Vietnam, electricity is an essential everyday consumer product that is exclusively distributed by the state. In a situation where the demand for electricity continues to increase and the electricity supply is lacking, the contributions of this study are of great significance to policy makers and the power sector in solving problems of supply-demand imbalance. Theoretically, this is the first study in Vietnam using the extended TBP model to comprehensively assess the impact of internal psychological factors (attitudes, subjective norms, perceived behavioral control and Personal moral norm) and external factors (Perceived benefit, Policy and Social Propaganda) to better understand the impact on electricity saving behavior of residents. The study emphasizes the importance of external factors such as benefits, policies and social propaganda to residents' intention and behavior to save electricity. This study shows that behavioral intent cannot be taken as a proxy measure of behavior. This study also concludes that perceived benefits, policy and Policy and Social Propaganda also have a strong impact on energy saving behavior.

\section{CONCLUSIONS}

Firstly, considering the importance of perceived behavioral control factor to residents' intention of saving electricity, it is necessary to provide residents with instructions on economical use of electricity, manuals basic, and knowledge training programs on energy sources. They also need to be provided the information such as how to use energy economically and effectively; How to choose and use electrical appliances in the home safely and economically, to avoid electrical leakage. These measures can enhance people's knowledge and skills to save electricity and thus improve their cognitive behavioral control. In addition, these measures can also make people to realize that it is not difficult to save electricity when they follow the instructions and help them to form good habits of saving electricity.

Secondly, considering the importance of subjective norm, personal moral norm, policies and social propaganda to the people 's intention of saving electricity. We realize that advocacy saving energy transmission need to make residents realize that everyone has a responsibility and a duty to reduce electricity consumption and save electricity in favor of improving their personal moral norm. It is extremely necessary to add the energy-saving knowledge to the existing accessible knowledge framework for students. For primary school children, the awareness of energy saving has profound and sustainable effects. Propagating energy-saving solutions for children is the solution that helps the knowledge of energysaving to be created as habits and awareness among them when they are still in the school chair. Thereby, the children's habits and awareness of energy use in the future will be affected. If students support the propaganda and implementation of electricity saving, they will be the force that spread the energy saving activities to other objects such as friends, teachers, parents, etc. Therefore, the effectiveness of this activity is replicated.

Thirdly, considering the importance of perceived benefit, policy and social propaganda to the electricity saving behavior of residents. It is recognized that state agencies need to enhance the propaganda, widely and widely disseminate the law on economical and efficient use of energy, directives, guidelines and regulations on electricity saving to people in various forms. It is necessary to focus on regular and continuous propaganda in wards, communes and residential areas on how to choose and use energy-saving devices in the family. The State needs to develop more mechanisms to encourage people to use energy-saving equipment, renewable energy sources (such as solar energy). At the same time, sanctions are needed to strictly handle waste energy behavior. The propaganda forms need to be simple, flexible easy to understand, easy to remember and easy to follow. The propaganda content needs to clarify the meaning, importance and benefits of using energy saving effectively for family and society.

Finally, considering the importance of the benefit factor to power saving. According to the results recorded by the author's survey, currently, some households still feel that saving electricity only has economic benefits in reducing family costs They do not acknowledge properly the importance of saving electricity in protecting the environment. Most of them think that the main source of electricity supply comes from hydroelectricity. According to Decision No. 428/QD-TTg dated March 18, 2016 approving the adjustment of the national electricity development planning for the 2011-2020 period, with a vision to 2030; by 2020 , the electricity supply due to coal thermal will account for $49.3 \%$ and hydroelectricity will account for $29.5 \%$; By 2025, coal thermoelectricity will account for $55 \%$ and hydropower will account for $20.5 \%$. Therefore, in the field of communication, the state and the electricity industry need to study how to fully transmit information to people so that they can gradually change the thinking "electricity is an endless source of energy". Community should acknowledge that electricity sources have the possibility of depletion due to the exhausted resources. People need to be aware of the importance of economical use of electricity, which not only helps to reduce spending but also plays an extremely important role in combating climate change. Saving electricity will decrease the threat of fossil fuel exhaustion and greenhouse gas emissions, which is the main cause of global climate change, floods devastation, abnormally heated global temperature, drought, saline intrusion, etc. In addition to creating consensus and joining hands of the whole society in economical and efficient use of electricity, the 
Vietnam Electricity needs more transparency in production and business activities. The Government should consider changing the electricity tariff in the ladder of use to suit the current context.

\section{REFERENCES}

[1] Baulch, B., Duong Do, T., Le, T.H. (2018). Constraints to the uptake of solar home systems in Ho Chi Minh City and some proposals for improvement. Renewable Energy, 118:

245-256.

https://doi.org/10.1016/j.renene.2017.10.106

[2] Le, V.T., Pitts, A. (2019). A survey on electrical appliance use and energy consumption in Vietnamese households: Case study of Tuy Hoa city. Energy and Buildings, 197: 229-241. https://doi.org/10.1016/j.enbuild.2019.05.051

[3] MOIT. (2016). Power Development Plan 7 Revise.

[4] Wang, S., Lin, S., Li, J. (2018). Exploring the effects of non-cognitive and emotional factors on household electricity saving behavior. Energy Policy, 115: 171-180. https://doi.org/10.1016/j.enpol.2018.01.012

[5] Zhou, K., Yang, S. (2016). Understanding household energy consumption behavior: The contribution of energy big data analytics. Renewable and Sustainable Energy Reviews, 56: 810-819. https://doi.org/10.1016/j.rser.2015.12.001

[6] Cheung, L.T.O., Chow, A.S.Y., Fok, L., Yu, K.M., Chou, K.L. (2017). The effect of self-determined motivation on household energy consumption behaviour in a metropolitan area in southern China. Energy Efficiency, 10(3): 549-561. https://doi.org/10.1007/s12053-0169472-5

[7] Zhou, S., Teng, F. (2013). Estimation of urban residential electricity demand in China using household survey data. Energy Policy, 61: 394-402. https://doi.org/10.1016/j.enpol.2013.06.092

[8] Nilsson, A., Bergstad, C.J., Thuvander, L., Andersson, D., Andersson, K., Meiling, P. (2014). Effects of continuous feedback on households' electricity consumption: Potentials and barriers. Applied Energy, 122:

$17-23$. https://doi.org/10.1016/j.apenergy.2014.01.060

[9] Shi, H., Fan, J., Zhao, D. (2017). Predicting household PM2.5-reduction behavior in Chinese urban areas: An integrative model of theory of planned behavior and norm activation theory. Journal of Cleaner Production, 145:

64-73.

https://doi.org/10.1016/j.jclepro.2016.12.169

[10] Ding, Z., Wang, G., Liu, Z., Long, R. (2017). Research on differences in the factors influencing the energysaving behavior of urban and rural residents in China-A case study of Jiangsu Province. Energy Policy, 100: 252259. https://doi.org/10.1016/j.enpol.2016.10.013

[11] Abrahamse, W., Steg, L. (2009). How do sociodemographic and psychological factors relate to households' direct and indirect energy use and savings? Journal of Economic Psychology, 30(5): 711-720. https://doi.org/10.1016/j.joep.2009.05.006

[12] Mizobuchi, K., Takeuchi, K. (2012). The influences of economic and psychological factors on energy-saving behavior: A field experiment in Matsuyama, Japan. Discussion Papers 1206, Graduate School of Economics,
Kobe University.

[13] Zhang, B., Fu, Z., Huang, J., Wang, J., Xu, S., Zhang, L. (2018). Consumers' perceptions, purchase intention, and willingness to pay a premium price for safe vegetables: A case study of Beijing, China. Journal of Cleaner Production, 197: 1498-1507. https://doi.org/10.1016/j.jclepro.2018.06.273

[14] Ajzen, I. (1991). The theory of planned behaviour. Organizational Behaviour and Human Decision Processes, 50(2): 179-211. https://doi.org/10.1016/07495978(91)90020-T

[15] Ajzen, I., Fishbein, M. (2005). The influence of attitudes on behavior. The Handbook of Attitudes, Lawrence Erlbaum Associates Publishers, 173-221.

[16] Wang, Z., Zhang, B., Yin, J., Zhang, Y. (2011). Determinants and policy implications for household electricity-saving behaviour: Evidence from Beijing, China. Energy Policy, 39(6): 3550-3557. https://doi.org/10.1016/j.enpol.2011.03.055

[17] Zhang, Y., Wang, Z., Zhou, G. (2014). Determinants of employee electricity saving: The role of social benefits, personal benefits and organizational electricity saving climate. J. Clean. Prod., 66: 280-287. https://doi.org/10.1016/j.jclepro.2013.10.021

[18] Zhang, J., Zhang, W., Song, Q., Li, X., Ye, X.T., Liu, Y., Xue, Y.W. (2020). Can energy saving policies drive firm innovation behaviors? Evidence from China. Technological Forecasting and Social Change, 154: 119953. https://doi.org/10.1016/j.techfore.2020.119953

[19] Zhang, C.Y., Yu, B., Wang, J.W., Wei, Y.M. (2018). Impact factors of household energy-saving behavior: An empirical study of Shandong Province in China. Journal of Cleaner Production, 185: 285-298. https://doi.org/10.1016/j.jclepro.2018.02.303

[20] Wang, J., Tao, J., Chu, M. (2019). Behind the label: Chinese consumers' trust in food certification and the effect of perceived quality on purchase intention. Food Control, 108. https://doi.org/10.1016/j.foodcont.2019.106825

[21] Schwartz, S.H. (1977). Normative influences on altruism. Advances in Experimental Social Psychology, 10(1): 221-279. https://doi.org/10.1016/S0065-2601(08)603585

[22] Black, J.S., Stern, P.C., Elworth, J.T. (1985). Personal and contextual influences on househould energy adaptations. Journal of Applied Psychology, 70(1): 3-21. https://doi.org/10.1037/0021-9010.70.1.3

[23] Ajzen, I. (1991). The theory of planned behavior. Organ Behav Hum Dec, 50: 179-211.

[24] Gao, L., Wang, S., Li, J., Li, H. (2017). Application of the extended theory of planned behavior to understand individual's energy saving behavior in workplaces. Resources, Conservation \& Recycling, 127: 107-113. https://doi.org/10.1016/j.resconrec.2017.08.030

[25] Webb, D., Soutar, G.N., Mazzarol, T., Saldaris, P. (2013). Self-determination theory and consumer behavioural change: Evidence fromahousehold energy-saving behaviour study. Journal of Environmental Psychology, 35: 59-66. https://doi.org/10.1016/j.jenvp.2013.04.003

[26] Yadav, R., Pathak, G.S. (2016). Young consumers' intention towards buying green products in a developing nation: Extending the theory of planned behavior. J. Clean. Prod., 135: 732-739. https://doi.org/10.1016/j.jclepro.2016.06.120 
[27] Bertoldo, R., Castro, P. (2016). The outer influence inside us: Exploring the relation between social and personal norms. Resources, Conservation and Recycling, 112: 45-53. https://doi.org/10.1016/j.resconrec.2016.03.020

[28] Wang, X.W., Cao, Y.M., Park, C. (2019). The relationships among community experience, community commitment, brand attitude, and purchase intention in social media. Int. J. Inf. Manage., 49: 475-488. https://doi.org/10.1016/j.ijinfomgt.2019.07.018

[29] Wang, L., Wang, J., Huo, X. (2019). Consumer's willingness to pay a premium for organic fruits in china: A double-hurdle analysis. Int. J. Environ. Res. Public Health, 16(1). https://doi.org/10.3390/ijerph16010126

[30] Orbell, S., Crombie, I., Johnston, G. (1996). Social cognition and social structure in the prediction of cervical screening uptake. British Journal of Health Psychology, 1(Part 1): 35-50. https://doi.org/10.1111/j.20448287.1996.tb00490.x

[31] Tsujikawa, N., Tsuchida, S., Shiotani, T. (2016). Changes in the factors influencing public acceptance of nuclear power generation in Japan since the 2011 Fukushima Daiichi nuclear disaster. Risk Anal., 36(1): 98-113. https://doi.org/10.1111/risa.12447

[32] Wang, S., Wang, J., Lin, S., Li, J. (2019). Public perceptions and acceptance of nuclear energy in China: The role of public knowledge, perceived benefit, perceived risk and public engagement. Energy Policy, 126: $352-360$ https://doi.org/10.1016/j.enpol.2018.11.040

[33] Banfi, S., Farsi, M., Filippini, M., Jakob, M. (2008). Willingness to pay for energy-saving measures in residential buildings. Energy Econ., 30(2): 503-516. https://doi.org/10.1016/j.eneco.2006.06.001

[34] Considine, M. (1994). Public Policy: A Critical Approach. Macmillan Education Australia.

[35] Yuan, C., Liu, S., Fang, Z., Wu, J. (2009). Research on the energy-saving effect of energy policies in China: 1982-2006. Energy Policy, 37(7): 2475-2480. https://doi.org/10.1016/j.enpol.2009.03.010

[36] Nelson, R.A. (1996). A Chronology and Glossary of Propaganda in the United States. Greenwood.

[37] Olsen, M.E. (1981). Consumers' attitudes toward energy conservation. J. Soc. Issues, 37(2): 108-131. https://doi.org/10.1111/j.1540-4560.1981.tb02628.x

[38] McDougall, G.H.G., Claxton, J.D., Ritchie, J.R.B., Anderson, C.D. (1981). Consumer energy research: a review. J. Consum. Res., 8(3): 343-354.

[39] Tan, C.S., Ooi, H.Y., Goh, Y.N. (2017). A moral extension of the theory of planned behavior to predict consumers' purchase intention for energy-efficient household appliances in Malaysia. Energy Policy, 107: 459-471. https://doi.org/10.1016/j.enpol.2017.05.027

[40] Curtis, F.A., Simpson-Housley, P., Drever, S. (1984). Household energy conservation. Energy Policy (United Kingdom), 12(4).

[41] Sardianou, E. (2007). Estimating energy conservation patterns of Greek households. Energy Policy, 35(7): 3778-3791. https://doi.org/10.1016/j.enpol.2007.01.020

[42] Wang, Z., Zhang, B., Li, G. (2014). Determinants of energy-saving behavioral intention among residents in Beijing: Extending the theory of planned behavior. J. Renew. Sustain. Energy, 6(5): 53127. https://doi.org/10.1063/1.4898363

[43] Hair, J.F., Black, B., Babin, B., Anderson, R.E. (2010). Multivariate Data Analysis 7th Pearson Prentice Hall. Up. Saddle River, NJ.

[44] Nunnally, J.C. (1978). Psychometric Theory: 2d Ed," McGraw-Hill.

[45] Fornell, C., Larcker, D.F. (1981). Evaluating structural equation models with unobservable variables and measurement error. J. Mark. Res., 18(1): 39. https://doi.org/10.2307/3151312

[46] Anderson, J.C., Gerbing, D.W. (1988). Structural equation modeling in practice: $\mathrm{A}$ review and recommended two-step approach. Psychol. Bull., 103(3): 411 .

[47] Bagozzi, R.P., Yi, Y. (2012). Specification, evaluation, and interpretation of structural equation models. J. Acad. Mark. Sci., 40(1): 8-34. https://doi.org/10.1007/s11747011-0278-X

[48] Fornara, F., Pattitoni, P., Mura, M., Strazzera, E. (2016). Predicting intention to improve household energy efficiency: The role of value-belief-norm theory, normative and informational influence, and specific attitude. J. Environ. Psychol., 45: 1-10. https://doi.org/10.1016/j.jenvp.2015.11.001 